\title{
Rabbanite magical texts in Karaite manuscripts
}

\section{Gideon Bohak}

\author{
Tel-Aviv University
}

\begin{abstract}
In spite of the recurrent polemic in Classical Karaite texts against Rabbanite dealings with magic, later Karaite manuscripts do contain some magical texts and recipes. In the present study, we examine one such manuscript (Jerusalem - The National Library of Israel Ms. Heb. $8^{\circ} 3652$ ), a nineteenth-century Karaite compendium of magical and non-magical texts, copied in Troki in 1873 by Yehudah ben Shelamiel Zekharia Bezekowicz. Upon closer examination, many, and probably all, of the magical and divinatory texts and recipes found in this manuscript can be shown to be derived from the Jewish magical tradition, as transmitted in Rabbanite manuscripts. We therefore point to some of these parallels, and show that this late-Karaite manuscript incorporates textual units that go back to late antique Jewish magic, to medieval and Renaissance Jewish magic, and to more modern Jewish magic, and that its magic-related contents display no specific Karaite features. It is simply a collection of Rabbanite magical traditions copied by Karaite scribes for their own use.
\end{abstract}

Keywords

Magic, Karaites, Rabbanites, manuscripts, Troki

The magical and divinatory texts found in Karaite manuscripts of the Modern era are something of an anomaly. ${ }^{1}$ Given the recurrent polemic in Classical Karaite texts against the Rabbanite practice of magic (for which see MANN

${ }^{1}$ My interest in Karaite magical texts was awakened by Piotr Muchowski, who shared with me his work on MS Abkowicz 3, but while this paper would never have been written without his assistance, any errors it might contain are entirely my own. 
1935: 55-57, 75-83 and HARARI 2007: 84-87), one would not expect the Karaites themselves to have been involved in exactly the same activity. But whereas this may have been true for the earlier periods of Karaite history, in later periods, probably from the seventeenth century onwards, we find more and more evidence of the Karaite interest in magical texts and practices. This evidence has rarely been studied, and it is due to the renewed interest in these texts by Piotr Muchowski, and his extensive work on a long manuscript of nineteenth century Karaite literature, folklore, magic and divination, that we are slowly becoming familiar with these hitherto neglected texts (see Muchowski 2012). In the following paper, I wish to focus on one nineteenth century Karaite manuscript, and trace back the ultimate origins of some of the magical texts found therein. My main goal is to demonstrate that many, and perhaps even all, of the magical texts and practices found in this manuscript are found at a much earlier date in Rabbanite magical manuscripts and in their printed books of magic. To do so, I shall not try to identify earlier Rabbanite parallels for each of the more than three hundred texts and recipes found in this manuscript, but rather focus on a small group of such textual units, whose ultimate origins lie in very different historical contexts, from late antique Palestine to medieval and Renaissance Europe. In so doing, I do not wish to present a complete picture of the textual history of Modern Karaite magic, but to offer one example of how research in this field could be conducted.

The manuscript which stands at the basis of the following analysis is MS J erusalem - The National Library of Israel Ms. Heb. $8^{\circ} 3652$ (which is \#B $210(3652=8)$ at the Institute of Microfilmed Hebrew Manuscripts). ${ }^{2}$ This is a nineteenth century manuscript, currently consisting of 121 folios, and written mostly in Hebrew, with numerous loanwords from other languages. As noted on its first page, and partly repeated on fol. 15v, it was copied in 1873 , in Troki, by Yehudah ben Shelamiel Zekharia Bezekowicz, of whom Abraham Kahana noted that he "was the Karaite sage in Troki and then renounced his

${ }^{2}$ A useful facsimile of the entire manuscript is available online, and accessible through the website of the Institute of Microfilmed Hebrew Manuscripts, at http://aleph.nli. org.il:80/F/?func=direct\&doc_number=000042580\&local_base=NNLMSS. 
office, shaved his beard, and became a clerk and a bookkeeper in Solomon Kogin's tobacco factory in Kiev, and passed away there ca. 1911."3

A comparison of this manuscript and of manuscript Abkowicz 3, a Karaite manuscript copied in Troki in 1830, shows that most of the textual units in our manuscript were copied from that earlier manuscript, which Muchowski is currently preparing for publication. However, as I had no access to photographs of Abkowicz 3, and as my interest lies less in the nineteenth-century copies of the magical texts and morein their ultimate origins, I decided to take the later manuscript as my starting point for the present study. Moreover, my comparison of this manuscript with Muchowski's transcription of Abkowicz 3 convinced me that Bezekowicz was a good copyist, who copied his sources very carefully, and whose work can therefore serve as a reliable point of departure for our philological-historical quest.

The Karaite origins of both manuscripts are in no doubt. Not only is Bezekowicz known to us from other historical records, and from the other manuscripts he copied, this specific manuscript furthermore contains some Karaite polemics, aimed against the Rabbinic laws of kashrut (fol. 28r), as well as numerous citations of Karaite sources, including Kaleb Afendopolou, Isaac b. Abraham of Troki, and many others. But whereas this manuscript includes many non-magical texts, including riddles, poems, polemics, and so on, there is no doubt that the bulk of its contents deal with magic and divination. ${ }^{4}$

Looking at the magical and divinatory texts found in this extensive florilegium, we may immediately sense that they stem from many different sources. The manuscript itself occasionally cites the sources from which certain textual

3 This note is found in ms J erusalem - The National Library of Israel Ms. Heb. $8^{\circ} 5204$ (B 378 (5204 =8)), at the beginning of the manuscript, and runs as follows: כתב ידו של ביזיקוביץ מי שהיה חכם הקראים בטרוקי ואח"כ חלל את כהונתו וגלח את זקנו ונעשה פקיד

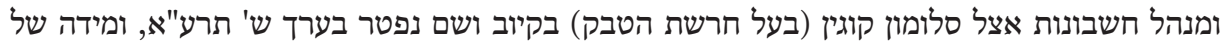

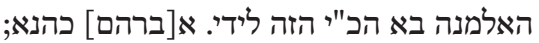
I have taken these data from the IMHM catalogue, and cf. MANN 1935: 554-555, n. 7.

${ }^{4}$ For a fuller description of the manuscript and its contents, see Muchowski's Folklore of the Karaites in Lithuania: Yehuda Bezekowicz Manuscript from Troki, 1873 (forthcoming). 
units have been taken, and these include several different types of sources, as we shall see below. Moreover, the different recipes display a mixture of loanwords from many different languages, including Latin, Italian, and Polish, a sure sign of the texts' different origins and complex transmission histories. However, in order to make more specific claims, and identify the transmission histories of specific textual units, one must examine each of the manuscript's texts and recipes against the wider background of the J ewish magical tradition. Of special importance in this respect is the search for parallels for each specific textual unit in earlier Jewish magical texts, both in manuscripts and in printed books. Unfortunately, such a search is hampered by the inadequacy of the research tools in this emerging field, as no one has yet indexed, or even mapped, the Jewish magical tradition (see BoHAK 2009; HARARI 2011). In light of this situation, I did not even try to identify all the sources from which our compiler compiled his magical florilegium, and at this stage in the study of the Jewish magical tradition a complete identification is not yet possible. However, I have identified quite a few sources, and can already demonstrate the great variety of these sources, and of the ultimate origins of the magical texts and recipes found in this nineteenth century manuscript. I therefore tried to arrange these sources chronologically, for while most of the J ewish magical texts cannot be dated with any precision, one can tell, at least in some cases, which texts are already attested in Late Antiquity, which ones are only attested from the Middle Ages onwards, and which ones are first attested only in the Renaissance or in the Modern period.

\section{(A) Late-Antique J ewish magic}

While the ultimate origins of the J ewish magical tradition lie in the Second Temple Period, it is first attested in its fully-developed form in Late Antiquity, in the period roughly from the fourth or fifth to the seventh centuries (see Вонак 2008). The J ewish magical texts and practices of this period were normally transmitted in Aramaic, display many Greco-Egyptian (and sometimes also Babylonian) influences, and in many cases were continuously copied into the Middle Ages and all the way to our own times. In the manuscript studied here, there are several 
magical and divinatory texts whose ultimate origins lie in this early stage of the history of the Jewish magical tradition, and I would like to briefly mention three such texts, and then offer a more detailed analysis of a fourth one.

Among the many divinatory texts embedded in our manuscript, at least three texts, which are here copied in Hebrew, began their lives in Aramaic versions, which are well-attested in the Cairo Genizah. In all three cases, the translation of the texts from their original Aramaic versions to the Hebrew ones was carried out in the early Middle Ages, by Rabbanite J ews who were no longer fluent enough in Aramaic to use such technical literature. These Hebrew versions then circulated in numerous manuscripts, and eventually made it even to the nineteenth-century Karaite manuscript studied here.

The first of these texts is found on fol. 61r-64r of our manuscript (and in Abkowicz 3, fol. 265r-268v), and is called ענין רפופות, "The Matter of Twitches." It deals with palmomancy, or twitch-divination, i.e., the foretelling of future events in a person's life from the involuntary twitches of different parts of the body, arranged from head to foot. For example, אם ראשו רופף יריב עם אדם, ואם מוח ראשו ילך למקום אחר ויבוא בשלום, If his (whole) head twitches, he shall fight with a man, and if the top of his head (twitches), he shall go to another place and arrive in peace." This divinatory technique is of extremely ancient origin, and is already attested in cuneiform literature; it then spread far and wide, and is attested in more than a dozen languages, including Greek, Syriac, Arabic, Sogdian, Turkish, and so on. In the J ewish world, it is first attested in a Palestinian Aramaic version that is known from two Cairo Genizah fragments (Oxford Bodleian MS Heb. g. 8.47-48 and g. 8.49), which I am planning to publish elsewhere. In the Middle Ages, there were several different Hebrew palmomantic texts in circulation in the J ewish world, but the one found in our manuscript, and which is well attested in numerous Rabbanite manuscripts and printed books, clearly is based on a translation of the abovementioned Aramaic version (and see also Muchowski 2012). Thus, the lateantique Palestinian origins of this text are hardly in doubt.

A second text that clearly goes back to late-antique J ewish sources is usually known by its Aramaic name, "Siman(ei) Mitra de-Kula Shatta," or, "The Sign(s) of the Rain for the Whole Year." It is found on fol. $47 \mathrm{v}-48 \mathrm{v}$ of our 
manuscript, and on fol. 371r-372r of Abkowicz 3. This text instructs you to watch the weather on three days in the month of Tammuz, from the thirteenth to the fifteenth of the month, and allows the foretelling of the weather-conditions for the following year. For example, 'אם יהיה מעונן יום יג' דע שיהיה מטר בד חדשים ראשונים תמוז אב אלול תשרי, "If it is cloudy on the thirteenth, know that it will be rainy on the first four months (of the year), Tammuz, Av, Elul and Tishrei." Here too the technique is based on much older Ancient Near Eastern divinatory techniques, which probably made their first entry into the Jewish world in an Aramaic version. But this Aramaic version was translated into Hebrew at an early date, and the Hebrew version circulated far and wide in numerous manuscripts and printed books, including many prayer-books and calendarical treatises (see LeIcht 2006: 75-77). Thus, the fact that Karaite scribes too found this text interesting is hardly surprising.

A third such text, which is often found in the Hebrew manuscripts sideby-side with the "Simanei Mitra" text, is usually known as "Shaar ha-Hittim" or "The Price of Wheat." It is found in our manuscript on fol. 49r, right after the "Simanei Mitra" text (and on fol. 372r-v in MS Abkowicz 3). This text allows you to know in advance the prices of wheat by examining on which part of the Hebrew month tekufat Tevet (the winter solstice) falls on that specific year. For example, אם מר"ח ועד ד' ימים יהיה נופלת זול יהיה, "If it (the tekufah) falls between the beginning of the month and the fourth (of the month), it (the wheat) will be cheap." The original Aramaic version of this text is attested in the Cairo Genizah and it circulated, in its Hebrew version, in numerous medieval J ewish manuscripts (Lегснт 2006: 73-75). In our manuscript (and in Abkowicz 3), this tradition is attributed to R. Moshe ha-Darshan, the eleventh century Provençal Rabbi, an attribution that is well attested in earlier Rabbanite manuscripts as well (LEICHT 2006: 131, 143, 145).

Thus far we have briefly touched on three examples of ancient Jewish divinatory texts and techniques that circulated throughout the Middle Ages and made their way even to our nineteenth century Karaite manuscript. We may now turn to a magical text, and offer a more detailed philological analysis of its transmission history. As a clear example of the "survival" of late-antique J ewish magic in our manuscript, we may look at recipe no 28 , found on 
fol. 72v, lines 1-9 (with an exact parallel in MS Abkowicz 3, fol. 272r-v). The recipe runs as follows ${ }^{5}$

$$
\begin{aligned}
& \text { אם תרצה ללכת לפני מלך או שלטון / לעשות שאלתך קח מצנפת של עור / וכתוב עליו אלו }
\end{aligned}
$$

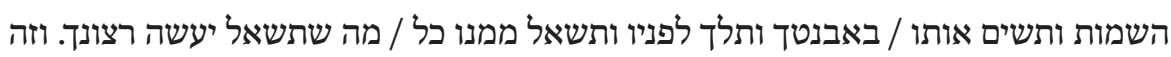

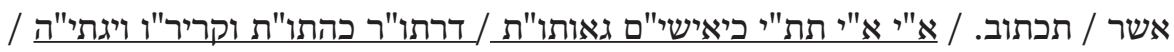

$$
\begin{aligned}
& \text { התית"י עת"ם יא"י, ותצליח בעזי תעז"ה. }
\end{aligned}
$$

If you wish to go before a king or a governor to do what you wish, take a leather turban (?) and write on it these Names, and place it in your girdle, and go before him (i.e. the king / governor) and ask of him all what you (wish to) ask, and he will do your wish. And this is what you should write: Y 'Y TTY KY'YŠYM G'WTWT DRTWR KHTWT WQRYRW WYTGYH HTYTY 'TMY'Y, and you will succeed, with God's help.

Reading this specific recipe, one would never know that it originally formed a part of a somewhat larger composition, called "The Seven Steps" (שבע מעלות) supposedly given to Adam by the angel Raziel after the Expulsion from Paradise. ${ }^{6}$ The exact date of composition of this text remains unknown, but its wide diffusion in J ewish magical manuscripts of the Middle Ages, and its relations to the Hekhalot literature (as noted below) would argue for a late antique or early-medieval date. The first of the seven "steps" of this text, as found in a fifteenth-century Jewish manuscript, runs as follows ${ }^{7}$

5 The scribe wrote all the sacred Names and "words of power" in larger, square letters. In my transcription, I underlined them instead.

${ }^{6}$ In fact, there are two different magical texts bearing this title and structured in the same manner; the first of these, which is written in Palestinian Jewish Aramaic, is amply documented in the Cairo Genizah (see, for example, MTKG II, 26, 2b and 27/1a-1b [=ScHÄFERSHAKED 1997: 105, 119-120]) and in later J ewish manuscripts, and displays many signs of the influence of the Graeco-Egyptian magical tradition of Late Antiquity. The second, which is the one discussed here, is written in Hebrew and might stem from a somewhat later period. It has recently been printed as a part of Zacuto's Sefer Shorshei ha-Shemot.

${ }^{7}$ I cite the text from NYPL Heb. 190 (formerly Sassoon 56), p. 138, lines 92-52. This is a manuscript of which I am now preparing a full critical edition. For other copies of 
מעלה ראשונה: אם תרצה ללכת לפני השלטון או לפני מלך יעשה / שאלתו כל מה שישאל ומלי

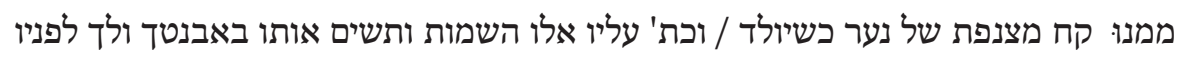

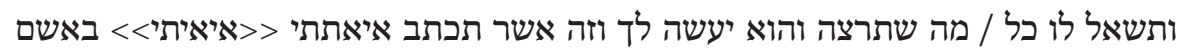

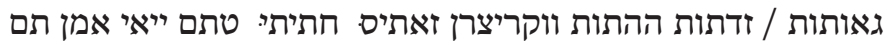

The first step: If you wish to go before a governor or before the king, (so that) he does everything that might be asked of him. Take the caul of a boy, when he is born, and write on it these Names, and place it in your girdle, and go before him (i.e., the governor / king) and ask of him whatever you wish and he will do it for you. And this is what you should write 'Y'TTY <<'Y'YTY>> B'ŠM G'WTWT ZDTWT HHTWT WWQRYZRRN Z’TYS HTTYTY ȚTM YY’Y. Amen. The end.

Reading the two recipes synoptically, we immediately note that this is the same recipe, and that the Karaite copyists did not make up this text, but copied it from older Rabbanite manuscripts. But we may also note some important differences, all of which reflect the textual entropy undergone by such recipes during the many centuries of copying from one manuscript to the next. First, we note how the original recipe asked for the use of the caul of a newborn child as a writing surface, a practice that we might find disgusting, but which fits well within the common practices of ancient and medieval Jewish, Muslim (cf. DJERIBi 1993) and Christian magic, where babies born with a caul were considered especially blessed, and the caul itself was attributed with apotropaic powers. But in the nineteenth century copy, we can see how somewhere along the line of transmission the word נער was misread as עור, and the word שיולד fell out of the text. Thus, instead of a caul of a newborn child, the nineteenth century users of this recipe were asked to use a leather turban (or, if they punctuated עור differently, the turban of a blind man). But an even more telling difference has to do with the list of magic names that one has to write. In the fifteenth-century manuscript, we can clearly see that the list of

this text see, e.g., Moscow, Guenzburg 302 (IMHM, \#43027), fol. 96v-97v; Oxford, Bodleian 1965 (\#19127), fol. 71r-72r; Budapest, Kaufmann, A20 (\#2822), p. 286, etc. 
otherwise meaningless Names is alphabetically arranged, from aleph to yod, with one Name, the fourth, erroneously beginning with a zayin rather than a dalet. The next "step" in this text also uses magical names, beginning with the next letter, kaph, and again continuing alphabetically, up to the letter resh. This sequence of acrostically arranged Names is also found in a Hekhalot fragment from the Cairo Genizah, and in a Genizah magical recipe, both of which also prove its relative antiquity (see SCHÄFER 1984, G21 [=T-S K 21.95a]/1a, 1316, and cf. MTKG II, 34, 2b/1-8 [=SchäFER-SHAKEd 1997: 179]). But by the time we get to the nineteenth century copies of this recipe, a series of small errors in the copying of individual letters of the meaningless Names resulted in the complete destruction of any semblance of an alphabetically arranged list.

To sum up this example, we may note that here we see how a single recipe was lifted out of a text that originally contained seven similar recipes, and was gradually corrupted in the process of transmission. These processes are not due to some Karaite agenda, and are not even the fault of the Karaite copyists of this recipe, since the copies from which they copied probably contained these errors, and once textual entropy sets in, it is almost impossible to reverse, unless one has access to many different copies of the same recipe, and begins comparing them and choosing the better readings. This, of course, is the privilege of the scholar over the magician, and especially of the scholar who has easy access to the Institute of Microfilmed Hebrew Manuscripts in J erusalem.

To this specific example, a few others could easily be added - for example, on fol. 72v-73r, a recipe (no. 29; in Abkowicz 3 it is found on fol. 272v) intended to help a woman whose children die includes the writing of Psalm 126

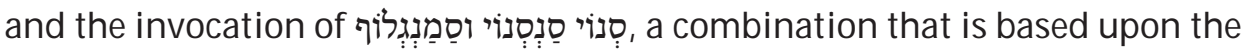
famous Shimmush Tehillim, or the "(Magical) Uses of the Psalms," which probably dates back to the $8^{\text {th }}$ or $9^{\text {th }}$ centuries (see REBIGER 2010: 102*, 238, 297). On fol. $115 \mathrm{r}$ there is a recipe for a dream request, involving the writing of an adjuration and a word-triangle with the magic word M'BRYT (i.e., מאברית אברית ברית רית ית ת, each word below the previous one) on a piece of parchment, and placing it under one's head when going to sleep. This practice, with the very same magic triangle, is well attested in the Cairo Genizah, 
and might even go back to late-antique sources (see BeLLusci 2011: 18, 51, 91). And on the very same page, there is a recipe for generating hatred between two persons by cooking an egg, writing upon it the victims' names, and letting a dog eat one half of the egg and a cat eat the other half. This practice too is well attested in the Cairo Genizah (and in medieval Christian sources), and it too might have much older precedents (see SAAR 2008: 153-154). Moreover, there is no doubt that a closer examination of each of the manuscript's recipes would come up with many more examples of recipes which are well attested in earlier J ewish magic.

\section{(B) Medieval and Renaissance J ewish magic}

Thus far we have focused on magical texts whose origins lie in Late Antiquity, or perhaps (in some of the later examples) in the early Middle Ages. But other magical texts found in our Karaite manuscript are distinctly medieval in origins. As an example of such a text, we may note recipe no. 200, which begins on fol. 103v and runs to fol. 105r (in MS Abkowicz 3, it is found on fol. 310v-311r). אם תקח עור נחש בהיות הלבנה בתוספת במעלה The text is untitled, and begins with "If you take the skin of a snake when the moon is waxing in the first degree of Aries, and you burn it then in a bronze cauldron whose opening is well covered." You will then obtain a pulverized powder, for which the text offers twelve different uses. ${ }^{8}$ For example, the fifth section tells you that if you place some of that powder under your right foot you will become the counselor of a king, and whoever asks your advice will subsequently follow it. The text ends by stating that "You must guard this powder, for it is precious; it is the prerogative of kings. And these are wonderful things, taken out of the books of those who experiment מוצאים מספרי) (המנסים), and do not hold it lightly." The text itself displays no clear signs of its origins, but it is a very well known medieval Latin medico-magical text which

8 The numbering in our manuscript (as well as in Abkowicz 3) is wrong, since the eighth section in fact contains two different "experiments," so the text only has eleven sections, but offers twelve uses of the magic powder. 
circulated far and wide, usually under the name of "The twelve Experiments of Johannes Paulinus" (see Johnsson 1913; Thorndike 1923: 794-796). It was translated into Hebrew on several different occasions (STEINSCHNEIDER 1893: 805-806), and is found in numerous medieval and later Hebrew manuscripts, including one version in which it is attributed to Solomon, the physician from Toledo, who is said to have taken it from an Arabic text. ${ }^{9}$

To this example, of a medieval Latin text translated into Hebrew and making it all the way to nineteenth century Karaite manuscripts, several more examples could be added, of medieval and Renaissance magical texts found in our Karaite manuscript. A clear example of this is a long set of medical and magical recipes which the compiler of our florilegium lifted out of Sod Yesharim, the book of segullot compiled by the famous Venetian Rabbi, Leo Modena (1571-1648), and printed anonymously in Venice in 1595, and in numerous subsequent editions (see Gries 1989: 95 and ChaJEs 2012: 255). Many of the recipes found in Modena's book clearly were taken by him from older sources, but Sod Yesharim's combination of table-tricks, riddles, and magical recipes, as well as the many Italian loanwords found on every page, display a distinct Italian Renaissance flavor. The book remained extremely popular in later times, and the appearance of many of its recipes in our manuscript is hardly surprising. In this case, we may even note how the compiler of our florilegium worked, since it is clear that he used Modena's book selectively, picking out the recipes he found useful and leaving the rest uncopied, and in some cases also rearranging the recipes in an order he found more useful. ${ }^{10}$

${ }^{9}$ See, for example, PARIs, B.N. 806 (\#12831), fol. 251r-252r; New York, J ewish Theological Seminary 8114 (\#11306), fol. 91r-v; Munich 228 (\#1259), fol. 115r-v (where the text is attributed to ג'ואן פוולי) and 182v; J erusalem, The National Library of Israel Ms. Heb. 8.857 (\#B 330 (857=28)), fol. 57v; St. Petersburg, Evr. II A 171/5 (\#64195), nos. 131-143; St. Petersburg, Inst. of Oriental Manuscripts of the Russian Academy A 78 (\#52332) (a Karaite MS), fol. 26r-v. See also London, British Library 12362 (GASTER 38) (\#8306) fol. 45r-46r (no. 116) (where the text is attributed to Solomon of Toledo), and cf. fol. 36r (no. 77) and fol. 40r (no. 89). And cf. LеIснт 2006: 157, 160.

10 See, for example, the recipes on fol. 88r-90v (=Abkowicz 3, fol. 292r-295r): recipe no. 123 is Modena's no. 93; recipeno. 124 is Modena's no. 98; no. 125is Modena's no. 3; no. 126 is Modena's no. 6; no. 127 is Modena's no. 7; nos. 128-132 are Modena's 
An even more interesting example of Renaissance magic is found on fol. 9r11r of our manuscript, a section that is not paralleled in MS Abkowicz 3. The text is written in a rather convoluted Hebrew, and carries no title; its first few lines run as follows

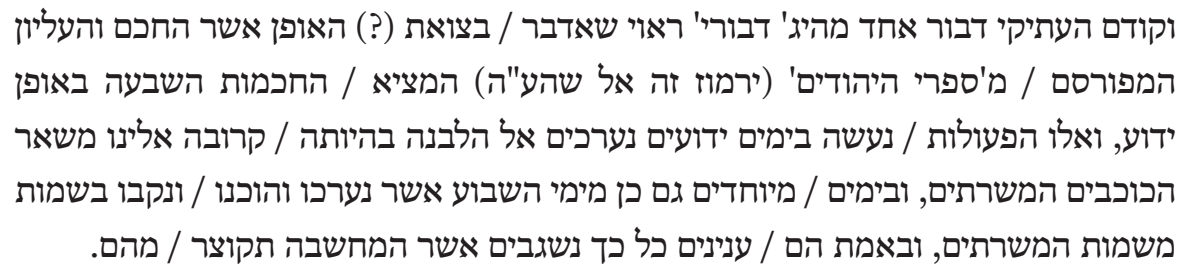

And before I copy one speech of the thirteen speeches, it is fitting that I should talk of the manner ${ }^{11}$ of the form in which the supreme sage, who is well-known from "the Books of the J ews" (this refers to King Solomon, may he rest in peace) invented the seven sciences in a known manner, and these actions we shall perform on specific days, set up towards the moon, as it is closer to us than the other servant stars, ${ }^{12}$ and also on specific days of the week, which were set up and prepared and listed by name with the names of the servants, and in truth these are matters that are so sublime that thought cannot reach them.

This enticing introductory passage is followed by instructions on how to use the thirteen "speeches," or prayers, or invocations, found in the text, but the text subsequently moves directly to the thirteenth "speech," which runs as follows (in order not to test the reader's patience, I leave out some of the more tedious parts)

nos. 10-14; no. 133 is Modena's no. 16; nos. 134-136 are Modena's nos. 18-20, and so on. Interestingly, a note before recipe 126 says סגולות מס' שבילי אמונה ("recipes from the book Shvilei Emunah"), and nos. 126 and 127 indeed are found in Meir Aldabi, Shvilei Emunah, 69a, but the following recipes seem not to be attested there.

${ }^{11}$ I take צואת as a copying error for צורת.

${ }^{12}$ I.e., the planets. 
בעזרת השם אעתיק דבור יג' מדיבורים י"ג וקודם / כל הדבור יתחיל בזה הלשון / הזכרון הבלתי

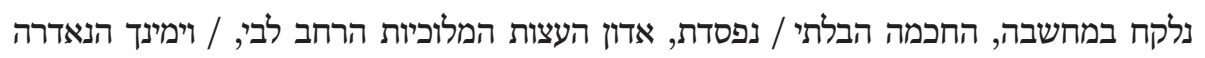

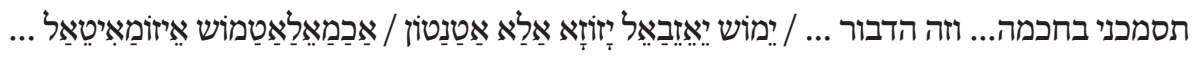

With the Lord's help I shall copy the thirteenth speech of the thirteen speeches, and prior to any speech, he should begin with this language: The remembrance that cannot be taken by thought, the incorruptible wisdom, the master of the royal advice, widen my heart, and your glorious right hand shall support me in wisdom... and this is the speech ... : IeMOS IeZeVaEL YaZOZA ALA ATaNaTONAKHaMaELATMOS EIZOMAITeAL ...

The text's overall style, its unusual Hebrew, and the Greek and / or Latin

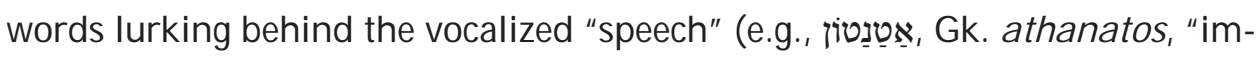
mortal"), all point to this text's origins in medieval or Renaissance Europe. A closer comparison with several J ewish manuscripts shows the text to be an excerpt from a much longer work, the מלאכת מושכלת, or "Intellectual Art," attributed to Apollonius of Tyana (see Steinschneider 1893: 848). As was recently noted by Reimund Leicht (2006: 369-370) this text in fact is a Hebrew translation of (one version of) the Ars Notoria, one of the most famous works of learned magic in the Christian Middle Ages. ${ }^{13}$ The Hebrew translation was carried out by Solomon ben Nathan Orgueiri of Aix-en-Provence, in the year 1393. This text may be found in several Hebrew manuscripts, and was described at some length by Yohanan Alemanno, the fifteenth-century student of various occult sciences, and the famous teacher of Pico della Mirandola. ${ }^{14}$ That this text, or at least one excerpt thereof, was still available, and of interest, to

${ }^{13}$ See also IDEL 2011: 205-206, who unfortunately was unaware of Leicht's work. For the Latin original, see VÉroNĖse 2007, esp. p. 55, where a sequence of magic words closely resembles the one in our manuscript ( "Gemot, Geel, Zabael, Gezezai, Azagra, Gezomai, Alla, Athanaton, Agyel, Azamiel, Athanayos, Ezomai," etc.). A close comparison of the Latin and Hebrew versions remains a scholarly desideratum.

${ }^{14}$ For the manuscript evidence, see Budapest, Kaufmann A 246 (IMHM Fiche 97), pp. 3-17; Bar-Ilan University 286 (\#36569), fol. 83r-92v; St. Petersburg, Inst. of Oriental Manuscripts of the Russian Academy B 247 (\#53384), fol. 9or-94v. For 
nineteenth century Karaites is a sure sign of the great attraction of such magical texts, which proved equally fascinating for some of the famous magicians of Western Europe at exactly the same time.

\section{(C) Modern J ewish magic}

Thus far we focused only on magical texts and recipes that were hundreds of years old by the time they were copied into our manuscript. However, the compilation of magical materials did not stop in the sixteenth or seventeenth century, and newer recipes and practices were constantly added into this witches' brew. As an example of such late materials, we may note a remedy against dysuria recommended on fol. 103r (no. 199; it is found on fol. 310r-v of Abkowicz 3)

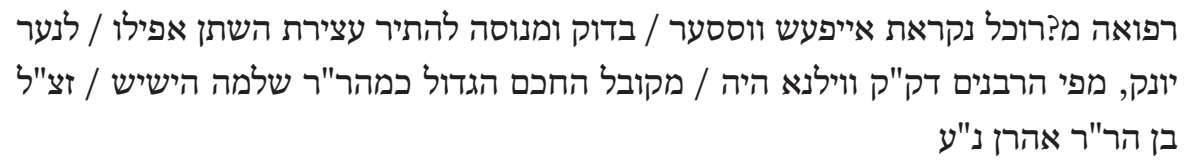

A medicine from a traveling-merchant (?), called Eipes? Wasser, tried and tested for stopping dysuria, even in a little boy (lit., a boy who still sucks milk), which the great sage, the old honorable rabbi Shlomo, the memory of the righteous is a blessing, the son of Rabbi Aharon, may he rest in peace, received from the Rabbis of the holy Community of Vilno.

In this case, we see how a medical / magical recipe is attributed to Shlomo (also known as Shlomo Yedidiah) ben Aharon, the Troki Karaite sage of the end of the seventeenth and beginning of the eighteenth century, who spent the years 1710-1719 in Vilna, and had close contacts with the Rabbanite J ews there (see Mann 1935: 570-572, 580, 687-688, 740-744; AKHIEzer and Lasker 2011: 99-102). Apparently, his acquaintances also shared with him some of

Alemanno's discussion, see his Sha'ar ha-Heshek, Livorno, 1790, fol. 4a-5a, with Rosenthal 1977: 350 and IdeL 1979: 311-312. 
their popular medicines, and he eventually recommended some of them to his fellow-Karaites, who kept on copying his advice even 150 years later.

A similar awareness of more modern magical beliefs and practices is displayed on fol. 100r, recipe no. 181 (=Abkowicz 3, fol. 306v-307r) ${ }^{15}$

הועתק מספר דוקטוריי"ה אשר תד"מ (=שגל) האדם / את אשתו כאשר ישאר חשק

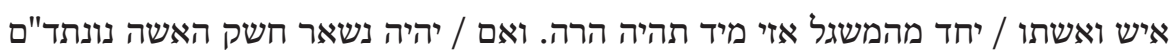
(=מהמשגל) ועדיין / האיש נתד"ם (=משגל) את אשתו אזי לא יולדו לה / בנים...

Copied from a book of doctors. When a man has intercourse with his wife, if the man and his wife both have some lust (?) remaining from the intercourse, then she will immediately become pregnant. But if the wife's lust (?) from the intercourse remains while the husband is still having sex with her, then she will have no children...

While the exact details of this piece of medical advice are not really clear, it is clearly taken from a "book of doctors." The entry of magico-medical lore taken from modern, and often printed, books of medicine into a J ewish magical recipe book is far from uncommon, and many similar examples could be adduced from other modern J ewish magical manuscripts (for example, BAREL 1991: 223, 229 and see Zinger 2009). The same phenomenon may still be seen in twentieth century printed books of J ewish magic, some of which even recommend antibiotics among their many spells and recipes (see Вонак 2008: 432). Such examples clearly show that the practitioners who used the magical handbooks were in no way oblivious to the rise of modern science, and especially the rise of modern medicine. In fact, they had no difficulty incorporating some of its claims and some of its remedies into their own handbooks.

Having examined many specific examples, we may now offer a broader conclusion - ms J erusalem Heb. $8^{\circ} 3652$ is a very typical Modern manuscript of

${ }^{15}$ In order to avoid writing some "dirty" words, the scribe encrypted them with a very simple abgad cipher, in which aleph becomes bet, bet becomes gimmel, and so on. I have added the deciphered words in parentheses. 
European Jewish magic; there is nothing specifically Karaite about any of its magical recipes, and most of them can be shown to derive from older Rabbanite sources. In part, this probably should be seen as a specific example of a wider phenomenon, namely, the general "Rabbinization" of later Karaite culture (and cf. Mann 1935: 685). In part, it may be due to the fact that even when magic was practiced by Rabbinic J ews and by well-known rabbis and transmitted by them, there often was very little that was specifically "Rabbinic" about it. But in part this is also due to the paradoxical fact that because of the vehement objection to magic in Classical Karaite literature, when later Karaites developed an interest in such practices it was only to their Rabbanite colleagues, who had been practicing magic from talmudic times onwards, that they could turn for help.

\section{Bibliography}

AkHIEzer, Golda and Lasker, Daniel J . 2011. Solomon ben Aaron of Troki and His Anti-Christian Treatise Migdal 'Oz. In: Dan D.Y. Shapira and Daniel J . Lasker (eds.), Eastern European Karaites in the Last Generations, J erusalem: Ben-Zvi, 97-129 (Heb.).

BAREL, Gabriel. 1991. Rav-Péalim - un manuel de médicine populaire de Maroc, in Issachar Ben-Ami (ed.), Recherches sur la Culture des J uifs d'Afrique du Nord, J erusalem: Communauté Israelite Nord-Africaine, 211232 (Heb.).

Bellusci, Alessia. 2011. Dream Requests from the Cairo Genizah, unpubl. MA Thesis, Tel-Aviv University.

Bohak, Gideon. 2008. Ancient J ewish Magic: A History, Cambridge: Cambridge University Press.

Вонак, Gideon. 2009. Prolegomena to the Study of the J ewish Magical Tradition, Currents in Biblical Literature 8, 107-150.

Chases, J effrey Howard. 2012. Too Holy to Print': Taboo Anxiety and the Publishing of Practical Hebrew Esoterica, J ewish History 26, 247-262.

DJERIBI, Muriel. 1993. L'Incantation Mythique: Noms et Écriture, Ethnologie Française 23, 94-103. 
Gries, Ze'ev. 1989. Conduct Literature (Regimen Vitae): Its History and Place in the Life of Beshtian Hasidism. J erusalem: Bialik (Heb.).

HARARI, Yuval. 2007. Leadership, Authority, and the Other in the Debate over Magic from the Karaites to Maimonides, The J ournal for the Study of Sephardic and Mizrahi J ewry 1, 79-101.

HARARI, Yuval. 2011. J ewish Magic: Outline and Comments, El Prezente 5, 13*85* (Heb.).

IdeL, Moshe. 1979. The Study Program of Yohanan Alemanno, Tarbiz 48, 303-331(Heb.).

IDEL, Moshe. 2011. Kabbalah in Italy, 1280-1510: A Survey. New Haven and London: Yale University Press.

Johnsson, J ohn William Schibby. 1913. Les 'Experimenta duodecim J ohannes Paulini', Bulletin de la Société Française d'Histoire de la Médecine et de ses filiales 12, 257-267.

LeIcht, Reimund. 2006. Astrologumena Judaica: Untersuchungen zur Ge schichte der astrologischen Literatur der Juden. [Texts and Studies in Medieval and Early Modern J udaism, 21], Tübingen: Mohr Siebeck.

Mann, J acob. 1931-1935. Texts and Studies in J ewish History and Literature, vol. 1, Cincinnati: Hebrew Union College Press, 1931; vol. 2. Philadelphia: J ewish Publication Society, 1935 (repr. of both volumes, New York: Ktav, 1972).

Muchowski, Piotr. 2012. Notes on Two Karaite Texts Edited by Ananiasz Zajączkowski, Folia Orientalia 49 [=Studia Andreae Zaborski Dedicata], 327-337.

Rebiger, Bill. 2010. Sefer Shimmush Tehillim - Buch vom magischen Gebrauch der Psalmen. Edition, Übersetzung und Kommentar, [TSAJ 137]. Tübingen: Mohr Siebeck.

Rosenthal, Erwin I.J. 1977. Yohanan Alemanno and Occult Science. In: Y. Maeyama and W.G. Saltzer (eds.). Prismata: Naturwissenschaftsgeschichtliche Studien (Festchrift für Willy Hartner). Wiesbaden: Franz Steiner, 349-361.

SAAR, Ortal-Paz. 2008. J ewish Love Magic: From Late Antiquity to the Middle Ages. unpubl. PhD dissertation, Tel-Aviv University (Heb.). 
SchäFER, Peter. 1984. Geniza-Fragmente zur Hekhalot-Literatur, [TSAJ, 6]. Tübingen: Mohr.

ScHäFER, Peter, and Shaked, Shaul. 1994, 1997, 1999. Magische Texte aus der Kairoer Geniza, [Texte und Studien zum Antiken Judentum 42, 64, 72]. Tübingen: J .C.B. Mohr (Paul Siebeck), 3 vols.

SteInschneIDER, Moritz. 1893. Die hebräischen Übersetzungen des Mittelalters und die J uden als Dolmetscher. Berlin (repr. Graz, 1956).

Thorndike, Lynn. 1923. A History of Magic and Experimental Science During the First Thirteen Centuries of Our Era. NewYork: Macmillan, vol. 2.

VéronÈse, Julien. 2007. L'Ars notoria au Moyen Âge: Introduction et édition critique, [Micrologus' Library, Salomon Latinus I]. Florence: Sismel - ed. del Galluzzo.

Zinger, Nimrod. 2009. "Who Knows What the Cause Is?": "Natural" and "Unnatural" Causes for Illness in the Writings of Ba'alei Shem, Doctors and Patients Among German J ews in the Eighteenth Century. In: Maria Diemling and Giuseppe Veltri (eds.). The J ewish Body: Corporeality, Society, and Identity in the Renaissance and Early Modern Period. Leiden: Brill, 127-155.

Professor Gideon Bohak teaches at the Department of J ewish Culture Studies, Tel-Aviv University. His fields of research include Second Temple and LateAntique J ewish literature, the Cairo Genizah, and especially the study of J ewish magic, from Antiquity to the Modern world. His most recent monograph is Ancient J ewish Magic: A History (Cambridge University Press, 2008). 